\title{
STRATEGI PENGEMBANGAN TERNAK SAPI POTONG BERORIENTASI AGRIBISNIS DI KECAMATAN KUTA BARO KABUPATEN ACEH BESAR
}

\author{
(The Development Strategy Of Agribussiness-Oriented Beef Cattle In District \\ Of Kuta Baro Aceh Besar)
}

\author{
Saina Hotmarida ${ }^{1}$, Agustina Arida ${ }^{1}$, T. Fauzi $^{1}{ }^{*}$ \\ Program Studi Agribisnis, Fakultas Petanian, Universitas Syiah Kuala
}

\begin{abstract}
Abstrak - Sapi potong merupakan salah satu ternak ruminansia yang mempunyai kontribusi terbesar sebagai penghasil daging. Selama ini produksi daging sapi di Indonesia belum mampu memenuhi permintaan dalam negeri yang cenderung meningkat setiap tahun. Oleh karena itu, pemerintah melakukan impor daging sapi dan bakalan antara lain Australia, Selandia Baru dan Amerika Serikat. Penelitian ini bertujuan untuk untuk menganalisis tenaga kerja, modal, teknologi dan pasar yang mempengaruhi jumlah populasi sapi potong dan menentukan strategi pengembangan usaha ternak sapi potong. Data yang digunakan dalam penelitian ini adalah data primer dan data sekunder. Metode analisis yang digunakan adalah dengan menggunakan regresi linier berganda dan analisis SWOT. Hasil penelitian menunjukkan bahwa Secara serempak variabel tenaga kerja, modal, teknologi dan pasar terima Ha tolak $\mathrm{H} 0$ dan signifikan terhadap jumlah populasi sapi potong. Secara parsial variabel tenaga kerja, modal, teknologi dan pasar terima Ha tolak H0 dan signifikan terhadap jumlah populasi sapi potong, sedangkan pasar tidak signifikan. Strategi yang perlu diterapkan adalah strategi internal kekuatan dan strategi eksternal peluang yakni memanfaatkan peluang dengan kekuatan yang ada.
\end{abstract}

Kata Kunci : Strategi Pengembangan, Sapi Potong, Agribisnis

\begin{abstract}
Beef cattle is one ruminants which has the largest contribution as a producer of meat. During the production of beef in Indonesia has not been able to meet growing domestic demand tends to increase every year. Therefore, the government has to import beef and feeder including Australia, New Zealand and the United States. This study aimed to analyze the labor, capital, technology and markets that affect the number of beef cattle population and determine the business development strategies of cattle. The data used in this study are primary data and secondary data. The analytical method used is by using multiple linear regression and SWOT analysis. The results showed that simultaneously variable labor, capital, technology and markets accept Ha reject $\mathrm{H} 0$ and significant impact on the number of beef cattle population. In partial labor, capital, technology and markets accept Ha reject H0 and significant impact on the number of beef cattle population, while the market is not significant. The strategy needs to be implemented is the strategy of internal strength and external strategic opportunities that take advantage of opportunities to the forces in the field.
\end{abstract}

Keywords: Strategy Development, Beef Cattle, Agribusiness

\section{PENDAHULUAN}

Sapi potong merupakan salah satu ternak ruminansia yang mempunyai kontribusi terbesar sebagai penghasil daging. Provinsi Aceh memiliki kemampuan yang relatif rendah dalam memproduksi daging sapi, hal ini karena tidak memenuhi antara permintaan daging sapi yang setiap tahunnya terus meningkat. Hal ini menyebabkan Provinsi Aceh menjadi salah satu pasar daging sapi yang sangat terbuka untuk wilayah lain dan ini merupakan sebuah 
tantangan dan peluang untuk pembangunan subsektor peternakan pada komoditas sapi potong di Provinsi Aceh.

Permasalahan yang di hadapi dalam pengembangan ternak sapi potong di Provinsi Aceh adalah masih kurangnya akses peternak sapi potong terhadap pemasaran, menurunnya genetik sapi potong, kecilnya skala kepemilikan ternak (2-4 ekor per keluarga), belum intensifnya pola pengembangbiakan sapi potong sehingga penggunakan teknologi buatan (IB) serta teknologi transfer embrio masih kurang optimal, dan masih terjadinya pemotongan sapi betina produktif dalam mencukupi kebutuhan daging sapi. Kondisi tersebut yang mengakibatkan rendahnya tingkat keberhasilan dan kualitas bibit yang dihasilkan sehingga akan menurun produktifitas sapi potong di Aceh Besar. (Saputra, 2008).

Tabel 1. Jumlah Populasi Ternak Sapi Potong Di Kabupaten Aceh Besar

\begin{tabular}{|c|c|c|c|c|c|c|}
\hline \multirow{3}{*}{ No } & \multirow{3}{*}{ Kecamatan } & \multicolumn{4}{|c|}{ Jenis Ternak (ekor) } & \multirow{3}{*}{$\begin{array}{c}\text { Jumlah Ternak } \\
\text { (ekor) }\end{array}$} \\
\hline & & \multicolumn{2}{|c|}{2014} & \multicolumn{2}{|c|}{2015} & \\
\hline & & $\begin{array}{l}\text { Jantan } \\
\text { (Ekor) }\end{array}$ & $\begin{array}{l}\text { Betina } \\
\text { (Ekor) }\end{array}$ & $\begin{array}{l}\text { Jantan } \\
\text { (Ekor) }\end{array}$ & $\begin{array}{l}\text { Betina } \\
\text { (Ekor) }\end{array}$ & \\
\hline 1 & Lembah Seulawah & 2,492 & 5,826 & 2,780 & 6,496 & 17,594 \\
\hline 2 & Seulimum & 892 & 8,914 & 1,096 & 9,933 & 20,835 \\
\hline 3 & Kota Jantho & 345 & 2,268 & 498 & 2,451 & 5,562 \\
\hline 4 & Kuta Cot Glie & 1,725 & 4,621 & 1,494 & 5,151 & 12,991 \\
\hline 5 & Indrapuri & 1,938 & 3,921 & 2,192 & 4,374 & 12,425 \\
\hline 6 & Kuta Meulaka & 598 & 945 & 767 & 1.295 & 2,311 \\
\hline 7 & Suka Makmur & 796 & 1,485 & 986 & 1,674 & 4,941 \\
\hline 8 & Simpang Tiga & 1,159 & 2,636 & 1,305 & 2,959 & 8,059 \\
\hline 9 & Darul kamal & 769 & 2,525 & 986 & 2,839 & 7,119 \\
\hline 10 & Darul imarah & 401 & 1,629 & 548 & 1,833 & 4,411 \\
\hline 11 & Montasik & 627 & 811 & 797 & 946 & 3,181 \\
\hline 12 & Ingin jaya & 1,346 & 595 & 1,584 & 697 & 4,222 \\
\hline 13 & $\begin{array}{l}\text { Krueng Barona } \\
\text { Jaya }\end{array}$ & 936 & 728 & 1,106 & 847 & 3,617 \\
\hline 14 & Kuta Baro & 3,596 & 7,084 & 3,985 & 7,920 & 22,585 \\
\hline 15 & Darussalam & 2,930 & 5,741 & 3,248 & 6,426 & 18,345 \\
\hline 16 & Baitussalam & 729 & 1,324 & 817 & 1,494 & 4,364 \\
\hline 17 & Mesjid Raya & 1,348 & 5,620 & 1,494 & 6,476 & 14,938 \\
\hline 18 & Peukan Bada & 548 & 1,036 & 608 & 1,196 & 3,388 \\
\hline 19 & Lhoknga & 365 & 818 & 408 & 946 & 2,537 \\
\hline 20 & Leupung & 337 & 779 & 379 & 946 & 2,441 \\
\hline 21 & Lhoong & 219 & 2,823 & 249 & 3,188 & 6,479 \\
\hline 22 & Pulau Aceh & 220 & 870 & 249 & 996 & 2,335 \\
\hline \multirow[t]{3}{*}{23} & Blang Bintang & 783 & 1,739 & 877 & 1,993 & 5,392 \\
\hline & Sub Total & 25,099 & 64,738 & 28,453 & 71,782 & 190,072 \\
\hline & TOTAL & \multicolumn{5}{|c|}{190,072} \\
\hline
\end{tabular}

Sumber : Dinas Peternakan dan Kesehatan Hewan Aceh Besar, 2015

Berdasarkan Tabel 1 diatas dapat diketahui bahwa Jumlah Populasi Ternak Sapi Potong yang Paling Banyak adalah di Kecamatan Kuta Baro, dengan jumlah ternak sebanyak 22.585 ekor. Hal ini Kecamatan Kuta Baro merupakan daerah yang potensial untuk pengembangan usaha ternak Sapi Potong karena iklim tropisnya sangat bangus, selain itu daerah ini merupakan daerah yang sangat dengan pegunungan. 
Adapun tujuan dari penelitian ini adalah untuk menganalisis tenaga kerja, modal, teknologi dan pasar yang mempengaruhi Jumlah populasi sapi potong dan menentukan strategi pengembangan usaha ternak sapi potong.

\section{METODOLOGI PENELITIAN}

Penelitian ini dilakukan di Desa Cot Preh dan Desa Ujong Blang Kecamatan Kuta Baro Kabupaten Aceh Besar, dengan pertimbangan bahwa daerah ini merupakan daerah yang potensial bagi peternak sapi potong. Dengan objek penelitian adalah pelaku dari setiap stakeholder (peternak sapi dan lembaga pendukung). Data yang digunakan dalam penelitian ini adalah data primer dan data sekunder. Populasi dalam penelitian ini adalah 314 peternak sapi potong yang berada di Kecamatan Kuta Baro, adapun sampel dalam penelitian ini adalah $10 \%$ dari populasi peternak yaitu 32 peternak. Metode analisis yang digunakan penelitian ini adalah metode deskriptif kuantitatif. Adapun rumus yang digunakan untuk regresi linier berganda yaitu sebagai berikut:

\section{a. Regresi Linier Berganda}

$$
\mathrm{Y}=a_{0}+b_{1} X_{1}+b_{2} X_{2}+b_{3} X_{3}+b_{4} X_{4}+e
$$

Dimana :

$$
\begin{array}{ll}
\mathrm{Y} & =\text { Jumlah populasi ternak sapi potong (Ekor/Tahun) } \\
X_{1} & =\text { Tenaga Kerja }(\mathrm{Rp} / \mathrm{Thn}) \\
X_{2} & =\text { Modal }(\mathrm{Rp} / \mathrm{Thn}) \\
X_{3} & =\text { Teknologi } \\
X_{4} & =\text { Pasar } \\
a_{0} & =\text { Konstanta } \\
\mathrm{e} & =\text { Faktor pembatas yang menyebabkan error tidak teliti } \\
b_{1} b_{2} b_{3} \quad \quad \quad=\text { Koefisien Regresi }
\end{array}
$$

Untuk menguji apakah variabel Tenaga Kerja $\left(\mathrm{X}_{1}\right)$, Modal $\left(\mathrm{X}_{2}\right)$, Teknologi $\left(\mathrm{X}_{3}\right)$ dan Pasar $\left(\mathrm{X}_{4}\right)$ secara bersama-sama (simultan) berpengaruh terhadap jumlah populasi sapi potong (Y) maka digunakan uji F.

$$
F_{(\text {hitung })}=\frac{R^{2} k}{\left(1-R^{2}\right)(n-k-1)} \ldots \ldots \ldots \ldots \ldots(\text { Nazir, } 2003)
$$

Kriteria Keputusan :

Ha : Tenaga Kerja, Modal, Teknologi dan Pasar berpengaruh terhadap jumlah populasi ternak sapi potong di Kecamatan Kuta Baro, Kabupaten Aceh Besar.

$H_{0} \quad$ :Tenaga Kerja, Modal, Teknologi dan Pasar tidak berpengaruh terhadap jumlah populasi ternak sapi potong di Kecamatan Kuta Baro, Kabupaten Aceh Besar

Dimana :

$F_{h}>F_{t}$, pada taraf nyata 0,05 maka terima Ha dan tolak $H_{0}$

1) $F_{h}<F_{t}$, pada taraf nyata 0,05 maka terima $H_{0}$ dan tolak Ha.

Untuk menguji pengaruh masing-masing variabel independen terhadap variabel dependen secara terpisah, maka digunakan uji t dengan rumus : ai SE

$\mathrm{t}_{\text {cari }}=\frac{a i}{\mathrm{SE} a i}$ (Nazir, 2003)

$t_{(\text {cari })}>t_{(\text {tabel })}$, pada taraf nyata 0,05 maka terima $H_{a}$ dan tolak $H_{0}$

$t_{(\text {cari })}<t_{(\text {tabel })}$, pada taraf nyata 0,05 maka terima $H_{0}$ dan tolak $H_{a}$

\section{b. SWOT}

menggunakan matriks IFAS (Internal Strategic Factors Analysis Summary), EFAS (External Strategic Factors Analysis Summary), matriks posisi dan SWOT (Strengths, Weakness, Opportunities, Threats), beberapa metode analisis yang digunakan dijabarkan sebagai berikut : 


\section{A. Analisis Deskriptif}

Aspek yang dianalisis adalah aspek keuangan yang meliputi jumlah produksi, harga jual dan tingkat keuntungan. Aspek produksi yang meliputi ketersediaan bahan baku, teknologi yang dipakai, proses produksi, mutu produk dan tenaga kerja. Aspek lingkungan eksternal meliputi sosial dan ekonomi, pemerintah dan kemajuan teknologi.

B. Analisis Tiga Tahap Perumusan Strategi

Hasil analisis tersebut akan dikembangkan menjadi beberapa alternatif strategi berdasarkan skala prioritas, ada tiga tahap formulasi strategi menurut David (2004), yaitu :

1. Tahap Input

Analisis lingkungan internal dan lingkungan eksternal

Analisis lingkungan internal untuk memahami kekuatan dan kelemahan, aspek yang dinilai antara lain keuangan, sumber daya manusia, produksi dan pemasaran. Sedangkan analisis lingkungan eksternalnya menghasilkan peluang dan ancaman bagi industri, aspek yang dinilai yaitu sosial dan ekonomi, pemerintah dan teknologi

2. Tahap pembobotan

Pada tahap ini merupakan teknik yang dilakukan untuk menentukan bobot dari faktor internal dan faktor eksternal. Penentuan bobot pada setiap peubah yang dibandingkan dengan skala 1,2,3,4 dan 5

\section{Matriks IFAS dan EFAS}

Setelah mengetahui faktor strategi internal, selanjutnya penyusunan tabel IFAS dan faktor eksternal dengan tabel EFAS.

a. Matriks IFAS

1. Menyusun faktor-faktor internal dalam kolom (kekuatan dan kelemahan)

2. Beri rating masing-masing faktor strategi internal sesuai besar kecilnya pengaruh yang ada pada faktor internal, mulai dari nilai 5 (sangat baik), 4 (baik), 3 (netral), artinya tidak kuat/tidak lemah, 2 (cukup baik), dan 1 (tidak baik) terhadap kekuatan dan nilai rating terhadap kelemahan bernilai sebaliknya.

3. Beri bobot untuk setiap faktor pada kolom bobot

4. Untuk scoring kalikan bobot dengan rating.

b. Matriks EFAS

1. Menyusun faktor-faktor eksternal dalam kolom (peluang dan ancaman)

2. Beri rating masing-masing faktorstrategi eksternal sesuai besar kecilnya pengaruh yang ada pada faktor eksternal, mulai dari nilai 5 (sangat baik), 4 (baik), 3 (netral) artinya tidak kuat/tidak lemah, 2(cukup baik), dan nilai 1 (tidak baik) terhadap peluang dan nilai rating terhadap ancaman bernilai sebaiknya.

3. Beri bobot untuk setiap faktor pada kolom bobot

4. Untuk scoring kalikan bobot dengan rating.

Bobot $=\frac{\text { Rating } \mathrm{x} \text { Total Bobot }}{\text { Total Rating }}$
Rating $=\frac{\sum x}{\mathrm{n}}$

Rating adalah nilai rata-rata (mean) atau nilai yang sering muncul (modus). Dimana nilai tersebut diperoleh dari informan kunci sebagai responden. Informan kunci adalah pihak terkait dalam strategi pengembangan usaha ternak sapi potong berorientasi agribisnis di Kabupaten Aceh Besar. 
Tabel 2. Matriks IFAS

\begin{tabular}{|l|l|l|l|}
\hline \multicolumn{1}{|c|}{ Faktor-Faktor Strategis Internal } & Bobot & Rating & Score \\
\hline $\begin{array}{l}\text { 1. Kekuatan } \\
\text { - Kekuatan 1 } \\
\text { - Kekuatan 2 Total Kekuatan (S) }\end{array}$ & & & \\
\hline \multicolumn{1}{|c|}{ Total Kelemahan (W) } & & & \\
\hline $\begin{array}{l}\text { 2. Kelemahan Kelemahan 1 } \\
\text { - Kelemahan 2 }\end{array}$ & & & \\
\hline \multicolumn{1}{|c|}{ Telisih Total Kekuatan - Total Kelemahan (S-W=x) } & & & \\
\hline
\end{tabular}

Sumber : Rangkuti, 2004

Tabel 3. Matriks EFAS

\begin{tabular}{|c|c|c|c|}
\hline Faktor-Faktor Strategis Eksternal & Bobot & Rating & Score \\
\hline $\begin{array}{l}\text { 1.Peluang } \\
\text { - Peluang } 1 \\
\text { - Peluang } 2\end{array}$ & & & \\
\hline Total Peluang $(\mathrm{O})$ & & & \\
\hline $\begin{array}{l}\text { 2.Ancaman } \\
\text { - Ancaman } 1 \\
\text { - Ancaman } 2\end{array}$ & & & \\
\hline Total Ancaman (T) & & & \\
\hline $\begin{array}{l}\text { Selisih Total Peluang-Total Ancaman } \\
\text { O-T=y }\end{array}$ & & & \\
\hline
\end{tabular}

Sumber : Rangkuti, 2004

C. Matriks SWOT

Tabel 4. Matriks SWOT

\begin{tabular}{|c|c|c|}
\hline IFAS & & Weakness (W) \\
\hline & Strengths (S) & Strategi \\
Opportunities (O) & Strategi & W-O \\
\hline & S-O & Strategi \\
Threats (T) & Strategi & W-T \\
\hline
\end{tabular}

Sumber : Rangkuti,2004

Keterangan :

Strategi S-O : Memanfaatkan seluruh kekuatan untuk merebut dan memanfaatkan peluang.

Strategi S-T : Meskipun menghadapi ancaman, tapi masalahmemiliki kekuatan secara internal.

Strategi W-O : Memanfaatkan peluang dengan meminimalkan kelemahan.

Strategi W-T : Meminimalkan kelemahan dan menghindari ancaman.

\section{HASIL DAN PEMBAHASAN}

Faktor-Faktor yang Mempengaruhi Jumlah Populasi Sapi Potong di Kecamatan Kuta Baro.

Terdapat faktor-faktor yang mempengaruhi jumlah populasi sapi potong di Kecamatan Kuta Baro seperti tenaga kerja, modal, teknologi dan pasar. Untuk mengetahui pengaruh 
faktor-faktor yang mempengaruhi jumlah populasi sapi potong maka dapat dilihat kita sebagai berikut.

\section{Tenaga Kerja}

Menurut Diah Retno (2008) Tenaga Kerja merupakan faktor penting dan perlu diperhitungkan dalam proses produksi komoditas pertanian. Tenaga kerja harus mempunyai kualitas berfikir yang maju saperti petani yang mampu mengadopsi inovasi-inovasi baru. Untuk lebih jelasnya pekerjaan utama responden peternak sapi potong yang berada di kecamatan kuta Baro.

Tabel 5 . Tenaga Kerja Ternak Sapi Potong di Kecamatan Kuta Baro Tahun 2016.

\begin{tabular}{|c|l|c|c|}
\hline No & \multicolumn{1}{|c|}{ Uraian Kegiatan } & Satuan & Rata-Rata/Tahun \\
\hline 1 & Membuat Kandang & Rp/HKP & 613.636 \\
\hline 2 & Memotong Rumput & Rp/HKP & 1.306 .534 \\
\hline 3 & Memelihara Sapi & Rp/HKP & 2.766 .534 \\
\hline \multicolumn{3}{|c|}{ Jumlah } & 4.686 .704 \\
\hline
\end{tabular}

Sumber : Data Primer (diolah), 2017

Berdasarkan tabel diatas terlihat biaya upah tenaga kerja pengembangan usaha ternak sapi potong dengan total sebesar Rp. 4.686.704 yang terdiri dari upah pembuatan kandang sebesar Rp.613.636. Memotong rumput ternak sapi potong sebesar Rp. 1.306 .534 dan Memelihara ternak sebesar Rp.2.686.704. biaya diatas adalah biaya yang dikeluarkan untuk satu ekor ternak sapi potong dalam satu tahun. Dapat disimpulkan bahwa biaya tenaga kerja yang paling banyak dikeluarkan adalah untuk biaya memelihara sapi. Hal ini menunjukkan peternak lebih banyak mengeluarkan biaya untuk tenaga kerja memelihara sapi potong.

Modal

Modal Adalah barang atau uang yang bersama-sama faktor-faktor produksi tanah dan tenaga kerja menghasilkan barang-barang baru yaitu dalam ini hasil pertanian (Mubyarto, 1989).

Tabel 6. Modal Peternak Sapi Potong di Kecamatan Kuta Baro Tahun 2016

\begin{tabular}{|c|l|c|r|}
\hline No & \multicolumn{1}{|c|}{ Uraian } & Satuan & Rata-Rata \\
\hline 1 & Pembuatan Kandang & Rp/Thn/Ekor & 1.142 .353 \\
\hline 2 & Bibit Sapi & Rp/Thn/Ekor & 41.176 \\
\hline 3 & Pembuatan Sumur & Rp/Thn/Ekor & 347.762 \\
\hline 4 & Obat-Obatan & Rp/Thn/Ekor & 265.544 \\
\hline \multicolumn{2}{|c|}{ Jumlah } & 1.796 .835 \\
\hline
\end{tabular}

Sumber : Data Primer (diolah), 2017

Berdasarkan Tabel 6 diatas menunjukkan bahwa modal yang dikeluarkan untuk pengembangan sapi potong sebesar Rp. 1.796 .835 yang terdiri dari biaya pembuatan kandang sebesar Rp.1.142.353, modal bibit sapi sebesar Rp.41.176, pembuatan sumur sebesar Rp.347.762 sedangkan obat-obatan sebesar Rp.265.544.

Hal ini menunjukkan bahwa peternak sapi potong lebih banyak mengeluarkan modal untuk pembuatan kandang, karena kandang merupakan fasilitas terpenting dalam beternak. Semakin banyak ternak semakin luas kandang sehingga modal yang dikeluarkan semakin besar.

\section{Teknologi}

Teknologi peternakan merupakan kegiatan mengembangbiakkan dan membudidayakan hewan ternak untuk mendapatkan manfaatkan dan hasil kegiatan tersebut. Di tempat penelitian sudah ada teknologi di terapkan oleh peternak sapi potong, adapun teknologi yang diterapkan adalah teknologi IB. Tujuan dari teknologi inseminasi buatan ini adalah untuk memudahkan peternak dalam membudidaya ternak sapi potong dan mudah dalam 
mendapatkan bibit sapi potong. Adapun pengaruh tingkat teknologi terhadap jumlah populasi sapi potong dapat dilihat tabel berikut.

Tabel 7. Tingkat Teknologi Peternak Sapi Potong.

\begin{tabular}{|c|l|c|c|}
\hline No & Kategori Teknologi & $\begin{array}{c}\text { Jumlah Peternak } \\
\text { Responden (Orang) }\end{array}$ & Persentase (\%) \\
\hline 1 & Sangat Setuju & 1 & 3,1 \\
\hline 2 & Setuju & 27 & 84,4 \\
\hline 3 & Ragu-Ragu & 4 & 12,5 \\
\hline & Jumlah & 32 & 100 \\
\hline
\end{tabular}

Sumber : Data Primer (diolah), 2017

Berdasarkan Tabel 11 diatas kita ketahui bahwa di daerah penelitian tingkat teknologi peternak dengan kategori setuju persentasenya jauh lebih besar dibandingkan yang lain, dimana persentase setuju sebesar $84,4 \%$. Hal ini menunjukkan di daerah penelitian dapat disimpulkan peternak setuju bahwa teknologi mempengaruhi jumlah populasi sapi potong. Di daerah penelitian teknologi yang diterapkan saat ini adalah teknologi IB, teknologi ini adalah tujuannya untuk menambah populasi sapi potong. Hal ini dapat dilihat pada lampiran 1 poin 15.

\section{Pasar}

Menurut Said dan Intan (2001), pemasaran pertanian merupakan sejumlah kegiatan bisnis yang ditujukan untuk memberi kepuasan dari barang dan jasa yang dipertukarkan kepada konsumen dalam bidang pertanian. Adapun pengaruh tingkat pasar terhadap jumlah populasi sapi potong dapat dilihat pada tabel berikut.

Tabel 8. Manfaat pasar terhadap agribisnis

\begin{tabular}{|c|l|c|c|}
\hline No & \multicolumn{1}{|c|}{ Kategori Pasar } & $\begin{array}{c}\text { Jumlah Peternak Responden } \\
\text { (Orang) }\end{array}$ & Persentase (\%) \\
\hline 1 & Iya & 24 & 75 \\
\hline 2 & Ragu-Ragu & 8 & 25 \\
\hline & Jumlah & 32 & 100 \\
\hline
\end{tabular}

Sumber : Data Primer (diolah), 2017

Dari Hasil diatas dapat disimpulkan bahwa peternak sapi potong setuju pasar merupakan bermanfaat terhadap agribisnis, hal ini karena pasar memang hal yang sangat penting di dalam agribisnis. Semakin penting pasar dalam agribisnis maka peternak sapi potong terus meningkatkan jumlah populasi sapi potong.

\section{Analisis Regresi Linier Berganda}

Analisis Regresi Linier Berganda merupakan analisis yang memiliki variabel bebas lebih dari satu disebut analisis regresi linier berganda. Teknik regresi linier berganda digunakan untuk mengetahui ada tidaknya pengaruh signifikan dua atau lebih variabel bebas $(\mathrm{X} 1, \mathrm{X} 2, \mathrm{X} 3, \ldots \ldots, \mathrm{k})$ terhadap variabel terikat $(\mathrm{Y})$.

\section{Uji Hipotesis Serempak (Uji F)}

Uji statistik $\mathrm{F}$ pada dasarnya menunjukkan apakah semua variabel bebas yang dimasukkan dalam model mempunyai pengaruh secara bersama-sama terhadap variable terikat/dependen. (Ghozali, 2001). Uji Hipotesis secara serempak digunakan untuk mengetahui pengaruh dari Variabel Independen secara keseluruhan terhadap Variabel Dependen

Tabel 9. Analisis Uji Hipotesis secara bersama-sama atau uji F

\begin{tabular}{|c|c|c|c|c|c|c|}
\hline \multicolumn{2}{|c|}{ Model } & $\begin{array}{l}\text { Sum of } \\
\text { Squares }\end{array}$ & $\mathrm{df}$ & Mean Square & $\bar{F}$ & Sig. \\
\hline \multirow{3}{*}{1} & Regression & 119.739 & 4 & 29.935 & 36.308 & $.000^{\mathrm{b}}$ \\
\hline & Residual & 22.261 & 27 & .824 & & \\
\hline & Total & 142.000 & 31 & & & \\
\hline
\end{tabular}


$\mathrm{F}_{\text {hitung }}=36,308$

$\mathrm{F}_{\text {tabel }}=2,74$

Dari tabel diatas diperoleh $\mathrm{F}_{\text {hitung }}=36,308$ dan $\mathrm{F}_{\text {tabel }}=2,74$, karena

$\mathrm{F}_{\text {hitung }}=36,308>\mathrm{F}_{\text {tabel }}=2,74$, maka disimpulkan terima $\mathrm{H}_{\mathrm{a}}$ dan tolak $\mathrm{H}_{0}$ dalam hal ini dapat diartikan secara bersama-sama variabel tenaga kerja, modal, teknologi dan pasar berpengaruh nyata terhadap jumlah populasi sapi potong.

\section{Uji Hipotesis Parsial (Uji t)}

Uji t digunakan untuk menguji secara pasial masing-masing variabel. Variabel Independen terhadap Variabel Dependen. Jika probabilitas nilai t atau signifikan < 0,05 maka dapat dikatakan bahwa terdapat pengaruh anatara variabel bebas terhadap variabel terikat secara parsial. Pada tabel berikut dapat kita lihat pengaruh variabel independen terhadap variabel terikat.

Tabel 10. Analisis Uji Hipotesis secara Parsial, Tenaga kerja, Modal, Teknologi dan Pasar.

\begin{tabular}{|c|c|c|c|c|c|c|}
\hline \multirow{2}{*}{\multicolumn{2}{|c|}{ Model }} & \multicolumn{2}{|c|}{ Unstandardized Coefficients } & \multirow{2}{*}{$\begin{array}{c}\text { Standardized } \\
\text { Coefficients } \\
\text { Beta }\end{array}$} & \multirow[t]{2}{*}{$\mathrm{t}$} & \multirow[t]{2}{*}{ Sig. } \\
\hline & & B & Std. Error & & & \\
\hline \multirow{5}{*}{1} & (Constant) & -8.293 & 2.702 & & -3.070 & .005 \\
\hline & Tenaga Kerja & 8.785E-008 & .000 & .343 & 3.132 & .004 \\
\hline & Modal & $3.524 \mathrm{E}-007$ & .000 & .606 & 5.510 & .000 \\
\hline & Tekonologi & .169 & .076 & .171 & 2.224 & .035 \\
\hline & Pasar & .217 & .160 & .104 & 1.360 & .185 \\
\hline
\end{tabular}

Berdasarkan Hasil analisis uji parsial, pengaruh tenaga kerja terhadap jumlah populasi sapi potong diperoleh $t_{\text {hitung }}=3,132$ dan nilai $t_{\text {tabel }}=2,055$, yang artinya $t_{\text {hitung }}>t_{\text {tabel }}$ maka terima Ha dan tolak H0. Hal ini dapat disimpulkan bahwa Tenaga kerja berpengaruh nyata (signifikan) terhadap jumlah populasi sapi potong.

Berdasarkan Hasil analisis uji parsial, pengaruh modal terhadap jumlah populasi sapi potong diperoleh $t_{\text {hitung }}=5,510$ dan nilai $t_{\text {tabel }}=2,055$, yang artinya $t_{\text {hitung }}>t_{\text {tabel }}$ maka terima Ha dan tolak H0. Hal ini dapat disimpulkan bahwa Modal berpengaruh nyata (signifikan) terhadap jumlah populasi sapi potong.

Berdasarkan Hasil analisis uji parsial, pengaruh teknologi terhadap jumlah populasi sapi potong diperoleh $t_{\text {hitung }}=2,224$ dan nilai $t_{\text {tabel }}=2,055$, yang artinya $t_{\text {hitung }}>t_{\text {tabel }}$ maka terima Ha dan tolak H0. Hal ini dapat disimpulkan bahwa teknologi berpengaruh nyata (signifikan) terhadap jumlah populasi sapi potong.

Berdasarkan Hasil analisis uji parsial, pengaruh pasar terhadap jumlah populasi sapi potong diperoleh $t_{\text {hitung }}=1,360$ dan nilai $t_{\text {tabel }}=2,055$ yang artinya $t_{\text {hitung }}>t_{\text {tabel }}$ maka terima Ha dan tolak H0, pasar tidak berpengaruh nyata (tidak signifikan) terhadap jumlah populasi sapi potong.

Berdasarkan pada tabel maka persamaan yang dibentuk untuk model regresi dapat dituliskan menjadi.

$$
\mathrm{Y}=-8,293+0,00000000878 \mathrm{X}_{1}+0,0000000352 \mathrm{X}_{2}+0,169 \mathrm{X}_{3}+0,217 \mathrm{X}_{4}
$$

Adapun interpretasi dari persamaan tersebut adalah sebagai berikut :

1. Hubungan antara tenaga kerja dan jumlah populasi sapi potong memberikan nilai positif. Artinya setiap peningkatan tenaga kerja sebanyak 1 orang, maka variabel jumlah populasi (Y) akan naik sebesar 0,00000000878 ekor. Untuk meningkatkan 1 ekor ternak sapi potong membutuhkan 9 orang tenaga kerja. Hal ini disebabkan karena tenaga kerja yang digunakan adalah untuk 3 pekerjaan yang harus diselesaikan dalam 1 tahun.

2. Hubungan antara modal dan jumlah populasi sapi potong memberikan nilai positif. Artinya setiap peningkatan modal sebesar Rp.1, maka variabel jumlah populasi (Y) akan meningkat sebesar 0,0000000352 ekor. Hal ini karena modal yang dibutuhkan untuk satu 
ekor sapi sebesar Rp. 1.796.835 dalam satu tahun, Semakin meningkatnya modal maka semakin banyak jumlah populasi sapi potong.

3. Hubungan antara teknologi dan jumlah populasi sapi potong memberikan nilai positif. Artinya setiap peningkatan teknologi yang digunakan peternak sapi potong $\left(\mathrm{X}_{3}\right)$ dalam pengembangan ternak sapi potong maka akan meningkatkan jumlah populasi potong (Y) sebesar 0,169 ekor. Hal ini terjadi semakin meningkatnya teknologi ternak sapi potong, maka semakin banyak jumlah populasi sapi potong.

4. Hubungan antara pasar dan jumlah populasi sapi potong memberikan nilai positif. Artinya setiap peningkatan manfaat pasar terhadap agribisnis, maka variabel jumlah populasi (Y) akan naik sebesar 0,217 ekor. Hal ini terjadi semakin meningkatnya manfaat pasar terhadap agribisnis maka populasi sapi potong akan meningkat.

\section{Analisis Faktor-Faktor Strategi Internal dan Strategi Eksternal (IFAS/EFAS)}

Analisis faktor strategi internal dan eksternal adalah pengolahan faktor-faktor strategis pada lingkungan internal dan eksternal dengan memberikan pembobotan dan rating pada setiap faktor-faktor strategis. Faktor strategis merupakan faktor dominan dari kekuatan, kelemahan, peluang dan ancaman yang memberikan pengaruh terhadap kondisi dan situasi yang ada serta memberikan keuntungan.

\section{Faktor Strategi Internal}

Analisis kekuatan faktor strategis internal/IFAS (Internal Strategic Factor Summary) Merupakan kesimpulan analisis dari berbagai faktor-faktor internal yang mempengaruhi keberlangsungan usaha ternak sapi potong yang terdiri dari kekuatan dan kelemahan. Masalah yang dominan harus ditentukan karena masalah akan mempengaruhi keadaan masa mendatang. Dalam analisis ini kita harus memahami apa saja yang termasuk dalam kekuatan dan kelemahan.

1. Kekuatan (Strenghths) adalah sumber daya, modal, keterampilan terhadap pesaing dan kebutuhan pasar. Berikut ini merupakan faktor-faktor kekuatan usaha ternak sapi potong di Kecamatan Kuta Baro.

a. Lokasi yang strategis

Lokasi Kandang peternakan dekat dengan rumah peternak sehingga memudahkan peternak dalam memelihara ternak sapi potong tersebut.

b. Teknologi Inseminasi Buatan (IB) yang digunakan sudah layak dan berhasil

Di Kecamatan Kuta Baro teknologi IB telah meluas, hal ini karena di Kecamatan Kuta Baro telah ada kebijakan pemerintah daerah penyuluhan ternak sapi potong, sehingga masyarakat Kecamatan Kuta Baro menjadi mudah memperoleh bibit dengan adanya teknologi IB tersebut.

c. Bibit mudah diperoleh

Bibit sapi potong sangat mudah diperoleh di Kecamatan Kuta Baro, hal ini karena telah meluasnya IB di masyarakat, disamping itu bibit ada juga yang berasal dari Cot Iri, dan Sibreh.

d. Mesin pemotong rumput yang digunakan sudah canggih

Mesin pemotong rumput yang digunakan di Kecamatan Kuta Baro sudah canggih, sehingga para peternak tidak banyak menghabiskan waktu.

e. Karyawan masih berasal dari keluarga

Karyawan peternak sapi potong yang berada di Kecamatan Kuta Baro masih berasal dari keluarga peternak itu sendiri.

f. Pengalaman beternak sudah banyak. 
Pengalaman beternak oleh masyarakat Kecamatan Kuta Baro cukup tinggi, karena usaha ternak sapi potong ini adalah usaha turun temurun dari orangtua sampai ke anak sehingga pengalaman beternak oleh masyarakat cukup tinggi.

2. Kelemahan (Weakness) adalah keterbatasan atau kekurangan dalam sumber daya, modal dan keterampilan yang secara efektif menghambat kinerja usaha ternak sapi potong. Keterbatasan tersebut dapat berupa fasilitas, keuangan, keterampilan dan managemen. Berikut ini faktor-faktor kelemahan usaha ternak sapi potong di Kecamatan Kuta Baro.

a. Teknologi budidaya masih tradisional

Teknologi budidaya di Kecamatan Kuta Baro masih alami/tradisional, hal ini karena keterbatasan modal yang dimiliki serta kepemilikan ternak sedikit. Penyebab lain karena secara turun temurun budidaya ternak sapi potong secara tradisional, sehingga mengikuti budaya yang ada.

b. Jumlah kepemilikikan ternak masih sedikit

Kepemilikan ternak sapi potong masih rendah hal ini karena modal yang dimiliki sedikit, tidak ada pinjaman kredit bank, sehingga untuk mengusahakan ternak sapi potong terbatas.

c. Belum ada pelatihan tentang ternak

Belum ada pelatihan atau seminar tentang cara-cara bagaimana beternak sapi potong secara intensif.

d. Keterampilan peternak lemah

Keterampilan peternak masih rendah, karena banyak feses sapi potong tidak digunakan sebagai pupuk kompos.

e. Mengusahakan ternak sapi sebagai sampingan

Usaha ternak sapi potong di Kecamatan Kuta Baro merupakan sebagai usaha sampingan untuk menambah ekonomi dalam rumah tangga, selain itu karena usaha ternak sapi potong ini merupakan usaha turun temurun dari keluarga.

f. Struktur Organisasi belum ada

Struktur petani belum ada karena kepemilikan ternak sapi yang masih rendah, sehingga belum ada organisasi di terapkan dalam pengembangan ternak sapi potong.

g. Proses perencanaan pengembangan ternak sapi masih rendah

Proses perencanaan pengembangan ternak sapi masih rendah, peternak tidak ada perencanaan rinci mulai dari pembuatan kandang sampe dengan pemasaraan.

h. Sistem Informasi masyarakat tentang ternak sapi belum ada diterapkan.

Menurut Kenneth dan Jane (2008), sistem informasi adalah sekumpulan komponen yang saling berhubungan, mengumpulkan , memproses, menyimpan, dan mendistribusikan informasi untuk menunjang mengambil keputusan dan pengawasan dalam suatu organisasi.

Di tempat penelitian sendiri, peternak belum ada menerapkan sistem infomasi ini, yang berupa mengumpulkan data, menyimpan dan mendistribusikan informasi tentang ternak sapi potong.

Hasil Indentifikasi faktor-faktor internal yang merupakan kekuatan kelemahan, rating dan pembobotan dipindahkan ke tabel matriks IFAS untuk diberi scoring seperti Tabel 11. 
Tabel 11. Matriks Evaluasi Faktor Strategi Internal (IFAS)

\begin{tabular}{|c|c|c|c|}
\hline Faktor-Faktor Strategis & Bobot & Rating & Score \\
\hline $\begin{array}{l}\text { Faktor-Faktor Internal } \\
\text { Kekuatan (Strengths) }\end{array}$ & & & \\
\hline 1. Lokasi yang strategis & 0.114 & 4 & 0.456 \\
\hline $\begin{array}{l}\text { 2. Teknologi Inseminasi Buatan (IB) yang digunakan } \\
\text { sudah layak dan berhasil }\end{array}$ & 0.114 & 4 & 0.456 \\
\hline 3. Bibit mudah diperoleh & 0.114 & 4 & 0.456 \\
\hline $\begin{array}{l}\text { 4. Mesin pemotong rumput yang digunakan sudah } \\
\text { canggih }\end{array}$ & 0.085 & 3 & 0.255 \\
\hline 5. Karyawan masih berasal dari keluarga & 0.085 & 3 & 0.255 \\
\hline 6. Pengalaman beternak cukup sudah banyak. & 0.137 & 4 & 0.456 \\
\hline 7. Pengetahuan tentang ternak sudah banyak & 0.137 & 4 & 0.456 \\
\hline Total Skor Kekuatan & & 26 & 2.79 \\
\hline Kelemahan (Weakness) & & & \\
\hline 1. Teknologi budidaya masih tradisional & 0.028 & 1 & 0.028 \\
\hline 2. Jumlah kepemilikikan ternak masih sedikit & 0.028 & 1 & 0.028 \\
\hline 3. Belum ada pelatihan tentang ternak & 0.028 & 1 & 0.028 \\
\hline 4. Keterampilan peternak lemah & 0.028 & 1 & 0.028 \\
\hline 5. Mengusahakan ternak sapi sebagai sampingan & 0.028 & 1 & 0.028 \\
\hline 6. Struktur Organisasi belum ada & 0.028 & 1 & 0.028 \\
\hline $\begin{array}{l}\text { 7. Proses perencanaan pengembangan ternak sapi } \\
\text { masih rendah }\end{array}$ & 0.028 & 1 & 0.028 \\
\hline $\begin{array}{l}\text { 8. Sistem Informasi masyarakat tentang ternak sapi } \\
\text { belum ada diterapkan }\end{array}$ & 0.028 & 1 & 0.028 \\
\hline Total Skor Kelemahan & & 8 & 0.224 \\
\hline TOTAL & & & 2.5 \\
\hline
\end{tabular}

Sumber: Data Primer (diolah), 2017

Tabel 11 menunjukkan bahwa faktor-faktor internal yang menjadi kekuatan dan kelemahan bagi agribisnis sapi potong. Adapun skor pada faktor kekuatan adalah 2,79 dan kelemahan 2,1

\section{Faktor Strategi Eksternal}

Analisis Kekuatan faktor strategis eksternal/EFAS (Eksternal Strategic Faktor Summary) merupakan kesimpulan analisis dari berbagai faktor-faktor eksternal yang mempengaruhi keberlansungan usaha ternak sapi potong yang terdiri dari peluang dan ancaman.

1. Peluang (Opportunities)

Peluang adalah situasi penting yang menguntungkan dalam lingkungan usaha ternak sapi potong. Berikut ini merupakan faktor-faktor peluang usaha ternak sapi potong di Kecamatan Kuta Baro.

a. Permintaan pasar terhadap daging sapi tinggi

Permintaan pasar atau konsumen terhadap daging sapi sangat tinggi, biasanya permintaan daging sapi ini pada hari-hari besar yakni hari meugang, acara pernikahan dan lain-lain

b. Harga daging sapi relatif tinggi

Harga daging sapi cukup relatif tinggi karena produksi daging sapi sapi tidak memenuhi permintaan pasar, sehingga harga daging sapi relatif tinggi. Adapun harga daging sapi pada saaat ini adalah $130 \mathrm{rb} / \mathrm{kg}$.

c. Adanya penyuluhan 
Adanya penyuluhan di Kecamatan Kuta Baro, masyarakat tidak kewalahan ketika sapi potong tersebut sakit karena di Kecamatan Kuta Baro telah ada petugas dari Kecamatan yakni Mantri Ternak.

d. Ketersediaan Limbah pertanian yang melimpah

Ketersediaan limbah pertanian yang melimpah di Kecamatan Kuta Baro, dengan melimpahnya limbah pertanian bisa dimanfaatkan sebagai pakan ternak sapi potong.

2. Ancaman (Threaths)

Ancaman merupakan pengganggu utama bagi posisi usaha ternak sapi potong yang dapat mengakibatkan kemunduran. Berikut ini merupakan faktor-faktor ancaman usaha ternak sapi potong di Kecamatan Kuta Baro.

a. Persaingan pemasaran sapi potong tinggi

Persaingan pemasaran tinggi, karena di Kecamatan Kuta Baro $80 \%$ beternak sapi potong. Peternak menjual sapi potongnya ke pedagang pengumpul, sementara pedagang pengumpulkan akan dominan memilih sapi yang sehat dan memiliki daging yang banyak

b. Musim kemarau

Ketika musim kemarau masyarakat Kecamatan Kuta Baro akan kesulitan dalam mencari rumput untuk pakan ternak sapi potong, hal ini karena keterbatasan lahan yang dimiliki

c. Teknologi budidaya masih tradisional

Pola pemeliharaan yang masih tradisional dan alami, hal ini karena keterbatasan modal yang dimiliki dan kepemilikan ternak yang masih rendah.

Hasil Identifikasi faktor-faktor eksternal yang merupakan peluang dan ancaman, rating dan pembobotan dipindahkan ke tabel matriks EFAS untuk diberi scoring (rating $\mathrm{x}$ bobot) seperti tabel dibawah berikut :

Berdasarkan Tabel 12, menunjukkan bahwa faktor-faktor eksternal yang menjadi peluang dan ancaman agribisnis sapi potong. Faktor-faktor peluang dan ancaman memiliki nilai skor 2.777 pada peluang agribisnis sapi potong dan nilai skor pada ancaman sebesar 0.333. Adapun faktor-faktor strategi peluang eksternal yaitu permintaan pasar terhadap daging tinggi, harga daging sapi relatif tinggi, adanya penyuluhan dan ketersediaan limbah pertanian yang melimpah.

Tabel 12. Matriks Evaluasi Faktor Strategi Eksternal (EFAS)

\begin{tabular}{|c|c|c|c|}
\hline Faktor-Faktor Strategis & Bobot & Rating & Score \\
\hline $\begin{array}{l}\text { Faktor-Faktor Eksternal } \\
\text { Peluang (Opportunities) } \\
\text { 1. Permintaan Pasar terhadap daging tinggi } \\
\text { 2. Harga daging sapi relatif tinggi } \\
\text { 3. Adanya Penyuluhan } \\
\text { 4. Ketersediaan limbah pertanian yang melimpah }\end{array}$ & $\begin{array}{l}0.166 \\
0.166 \\
0.222 \\
0.222\end{array}$ & $\begin{array}{l}3 \\
3 \\
4 \\
4\end{array}$ & $\begin{array}{l}0.498 \\
0.498 \\
0.888 \\
0.888\end{array}$ \\
\hline Total Skor Peluang & & 14 & 2.77 \\
\hline $\begin{array}{l}\text { Ancaman (Threats) } \\
\text { 1. Persaingan Tinggi } \\
\text { 2. Musim Kemarau } \\
\text { 3. Teknologi Budidaya masih tradisional }\end{array}$ & $\begin{array}{l}0.111 \\
0.055 \\
0.055 \\
\end{array}$ & $\begin{array}{l}2 \\
1 \\
1\end{array}$ & $\begin{array}{l}0.222 \\
0.055 \\
0.055\end{array}$ \\
\hline Total Skor Ancaman & & 4 & 0.332 \\
\hline TOTAL & 1 & & 2.43 \\
\hline
\end{tabular}

Sumber: Data Primer (diolah), 2017

Faktor strategi eksternal ancaman adalah persaingan tinggi, hal ini karena banyaknya peternak sehingga persaingan tinggi anatara peternak. Adapun ancaman selanjutnya pada agribisnis sapi potong adalah musim kemarau, hal ini ketika musim kemarau masyarakat 
Kecamatan Kuta Baro akan kewalahan mencari rumput atau hijauan untuk ternak mereka, keterbatasan lahan yang mereka miliki membuat mereka mencari rumput ke daerah bandara dan pegunungan dan teknologi budidaya masih tradisional . Faktor eksternal peluang yang selanjutnya adalah pola pemeliharaan masih tradisional, hal ini karena usaha ternak sapi potong ini merupakan usaha turun terumurun dari keluarga atau nenek moyang mereka.

\section{Matriks SWOT}

1. Jika $\mathrm{S}>\mathrm{W}$ dan $\mathrm{O}>\mathrm{T}$ maka strategi yang disarankan adalah strategi SO.

Strategi SO mencocokkan kekuatan internal dengan peluang ekseternal. Strategi ini menggunakan kekuatan yang dimiliki untuk merebut peluang.

Berdasarkan hasil analisis diperoleh beberapa strategi :

a. Meningkatkan populasi sapi potong dengan memanfaatkan IB

Peningkatan populasi sapi potong yaitu untuk memenuhi permintaan pasar atau konsumen, mengingat bahwa Kecamatan Kuta Baro merupakan daerah sentra sapi potong.

b. Penyediaan daging sapi yang bermutu

Penyediaan sapi yang bermutu, dengan sapi yang berkualitas otomatis harga daging semakin tinggi, semakin bermutu suatu produk maka semakin tinggi harga yang ditawarkan.

c. Memanfaatkan penyuluhan untuk mengolah limbah yang melimpah

Memanfaatkan penyuluhan atau dukungan dari pemerintah, apalagi daerah Kecamatan Kuta Baro daerah yang limbahnya yang melimpah seperti jerami dan lain-lain, sehingga sapi potong sehat dan memiliki daging yang berkualitas.

2. Jika $\mathrm{S}>\mathrm{W}$ dan $\mathrm{O}<\mathrm{T}$ maka strategi yang disarankan adalah $\mathrm{ST}$

Strategi ST mencocokkan kekuatan internal dengan ancaman eksternal.

Strategi ini menggunakan kekuatan untuk mengatasi ancaman eksternal.

a. Menerapkan pengalaman dan pengetahuan

Peternak sapi potong sebaiknya menerapkan ilmu yang diperoleh dari penyuluhan pada ternak, sehingga dengan diterapkannya ilmu yang telah ada jumlah produksi sapi potong agar meningkat seterusnya.

b. Menyiram rumput (Lahan) ketika musim kemarau

Melihat peternak kewalahan mencari rumput ketika musim kemarau, sebab rumput tidak bertunas sebaiknya peternak menyiram lahan rumput yang ada disekitar kandang ketika terjadi musim kemarau agar rumput tersebut bertunas kembali sehingga peternak tidak kewalahan lagi mencari rmput sapi potong, mengingat bahwa lokasi peternakan dengan rumah peternak maka

c. Meningkatkan Teknologi budidaya

Sebaiknya peternak meningkatkan teknologi budidaya ternak, sehingga populasi ternak semakin tahun meningkat dan memenuhi permintaan pasar. Dengan meningkatnya populasi peternak juga akan memperoleh keuntungan yang maksimal.

3. Jika $\mathrm{S}<\mathrm{W}$ dan $\mathrm{O}>\mathrm{T}$ maka strategi yang disarankan adalah strategi $\mathrm{WO}$

Strategi WO mencocokkan kelemahan internal dengan peluang eksternal.

Strategi ini memanfaatkan peluang untuk meminimalkan kelemahan.

a. Meningkatkan populasi ternak dan mengusahakan ternak sapi sebagai usaha utama Saat ini populasi ternak masih rendah karena peternak mangusahakan usaha sapi potong hanya sebagai sampingan saja untuk menambah pendapatan ekonomi rumah tangga, sebaiknya peternak membuat usaha ternak dengan skala besar sehingga daging dan poplasi juga semakin meningkat.

b. Membuat target maksimal untuk memenuhi produksi daging sapi 
Saat ini peternak belum mambuat target berapa maksimal jumlah produksi daging sapi yang dimiliki, sebaiknya peternak membuat rencana target produksi daging sapi sehingga peternak semakin termotivasi dalam mencapai target yang telah di rencanakan.

c. Memanfaatkan penyuluhan untuk meningkatkan keterampilan

Adanya dukungan pemerintah yakni penyuluhan dari dinas peternakan daerah, peternak sehusnya memanfaatkan peluang yang ada untuk meningkatkan keterampilan dalam mengusahakan usaha ternak sapi potong.

d. Meningkatkan teknologi budidaya

Adanya penyuluhan otomatis semakin luas wawasan peternak dalam mengusahakan usaha ternak sapi potong, sebaiknya peternak menerapkan teknologi yang canggih dalam budidaya sehingga populasi sapi potong juga meningkat.

4. Jika $\mathrm{S}<\mathrm{W}$ dan $\mathrm{O}<\mathrm{T}$ maka strategi yang disarankan adalah strategi WT

Strategi WT mencocokkan kelemahan intenal dan ancaman eksternal.

Strategi ini merupakan strategi bertahan yang diarahkan untuk meminimalkan kelemahan dan menghindari ancaman.

\section{KESIMPULAN DAN SARAN}

Berdasarkan hasil penelitian dan pembahasan maka dapat ditarik kesimpulan yaitu Secara serempak tenaga kerja, modal, teknologi dan pasar signifikan.. Secara parsial, variabel tenaga kerja, modal, teknologi berpengaruh nyata (signifikan) terhadap jumlah populasi sapi potong, sedangkan pasar tidak signifikan. Strategi yang perlu diterapkan adalah strategi internal kekuatan dan strategi eksternal peluang yakni memanfaatkan peluang dengan kekuatan yang ada.

Adapun Saran yang dapat diberikan penulis dalam penelitian ini adalah peternak diharapkan dapat meningkatkan SDM dan teknologi untuk mengembangkan usaha ternak sapi potong agar produksi daging sapi potong memenuhi terhadap permintaan pasar atau konsumen

\section{DAFTAR PUSTAKA}

David, F.R. 2001. Strategic Management Concepts and Cases. Prentice-Hall. Inc. New Jersey.

Ghozali, Imam. 2001. Aplikasi Analisis Multivariate dengan Program SPSS. Universitas Diponegoro. Semarang.

Kenneth and Jane. 2008. Sistem Informasi Managemen. Salemba Empat . Jakarta.

Nazir, Moh. 2003. Metode Penelitian. Penerbit Ghalia Indonesia. Jakarta.

Rangkuti, F. 2004. Analisis SWOT Teknik Membedah Kasus Bisnis. PT Gramedia Pustaka Utama, Jakarta.

Retno, D. 2007. Ekonomika Pertanian. Penerbit Swadaya. Jakarta 
Said, E.G, dan A.H.Intan. 2001. Managemen Agribisnis. Ghalia Indonesia dengan Magister Managemen Agribisnis. Program Pasca Sarjana. Institut Pertanian Bogor. Bogor.

Saputra, H. 2008. Strategi Pengembangan Ternak Sapi Potong Berwawasan Agribisnis di Provinsi Aceh (Thesis). Pasca Sarjana Institut Pertanian Bogor. Bogor 